\title{
The Assessment of Turkey's Lack of Resilience to Disasters and Hazards with IDB Indicator System
}

\author{
Ünal YAPRAK ${ }^{1}$, Turgut ŞAHINÖÖ ${ }^{2}$, Saime ŞAHINÖZ ${ }^{3}$
}

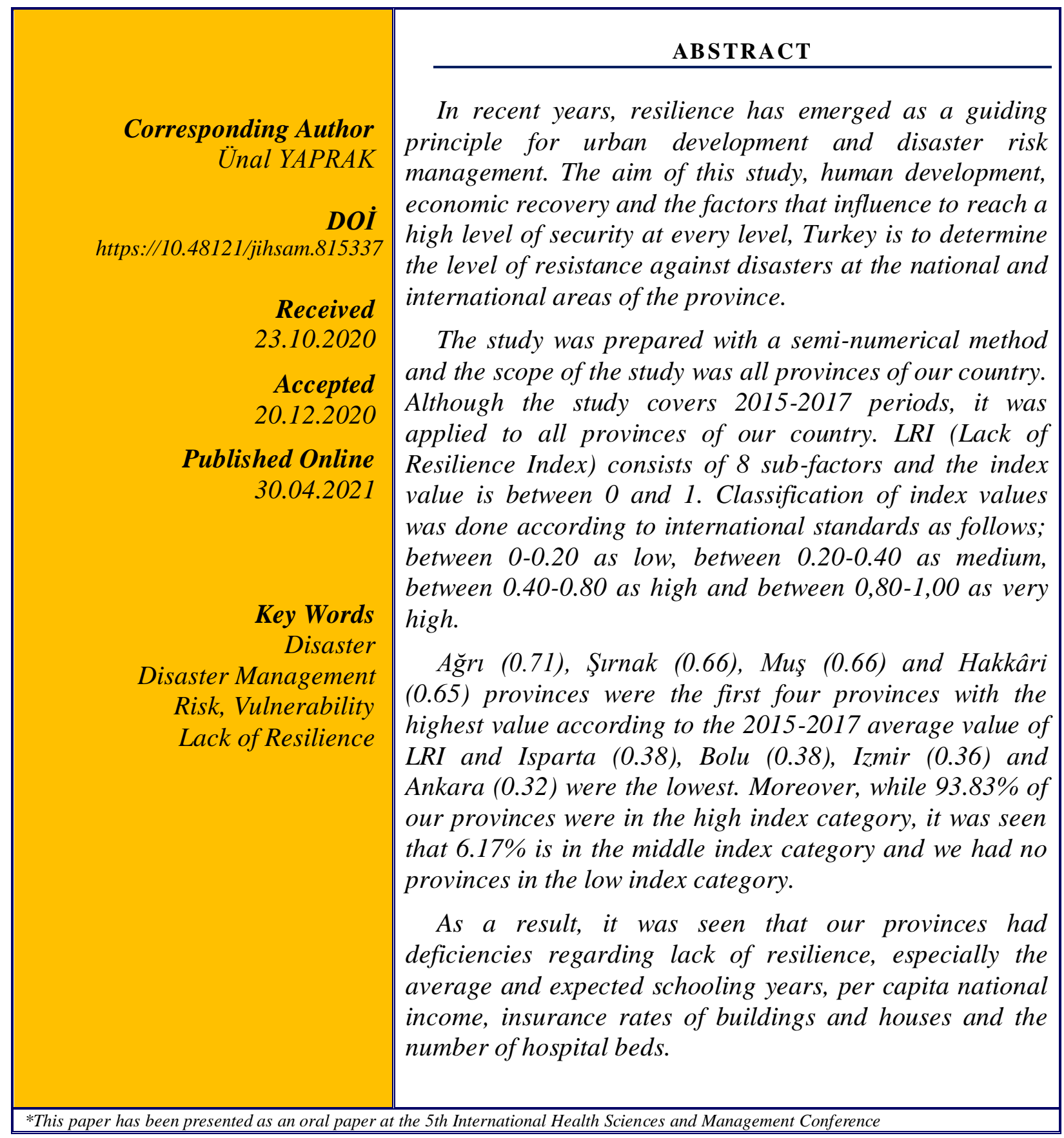

\footnotetext{
${ }^{1}$ PhD Graduates, Department Disaster Management, Gümüşhane University, Gümüşhane. unal_yaprak@hotmail.com. Orcid Number: 00000001-5745-3455

${ }^{2}$ Dr., Faculty of Health, Ordu University, Ordu. drsahinoz@ hotmail.com. Orcid Number: 0000-0001-8489-8978

3 Prof., Faculty of Medicine, Ordu University, Ordu. drsaime@ hotmail.com. Orcid Number: 0000-0003-0915-9344
} 


\section{INTRODUCTION}

Resilience is known as the ability to recoil or return after experiencing some stress or shock and is interpreted as the opposite of fragility (Pelling, 2011: 66). Resilience is used in the understanding of ecological changes and balances in the late 1970s and the mid-1990s that it was used in disaster risk reduction studies (ISMEP, 2014: 8). Although the terminology of disaster resilience is relatively new and is still under discussion, it is embedded in international policy frameworks for humanitarian action. Moreover, the issue of resilience is an important component of the approach to reduce the effects of disasters on vulnerability (Combaz, 2014: 1). Disaster resilience is the presence of structures and functions that are capable of effectively resisting, absorbing, adapting to and recovering from the effects of a hazard, including the conservation and restoration of the underlying state, community or society (UNDRR, 2009). The Disaster Risk Management Community regards resilience as coping without making it compulsory (Birkmann et al., 2013: 194).

Although resilience has different meanings in different disciplines, in the area of disaster risk management, all types of resilience such as ecological, environmental, institutional, infrastructural, organizational, economic, social, community, family and individual were all related to disaster risk management (Mac Askill and Guthrie, 2014: 668).

Disasters have long been regarded as one of the events that have been addressed through humanitarian response and relief efforts; but for several decades there has been a clear change of attitude towards strengthening preparations and a more effective and efficient response. In particular, an understanding emerged that the economy plays an important role and that a longer-term approach is needed to reduce disaster risk and increase resilience (UNDRR and WMO, 2012: 7). Increasing resilience prior to disasters means increasing the potential for saving more lives and further protection for future crises (Ranjan and Abenayake, 2014: 89).

In the last decade, resilience has emerged as a guiding principle for urban development and disaster risk management. However, the context of interpreting resilience as a guiding concept is dependent and open to interpretation (Mac Askill and Guthrie, 2014: 667). Resilience at the city level is defined as "the capacity of cities to operate, that is, people living and working in cities (especially poor and vulnerable) to be protected and developed, no matter what stresses or shocks they are exposed to" (UNU-CPR, 2016: 4). Urban disasters and violence have started to be on the agenda of humanitarian and development agencies. In addition, more and more initiatives are investing and testing smart and scalable solutions that promote citylevel resilience. Thanks to these initiatives, we witness that researchers, policy makers and private sector actors come together in a multidisciplinary way to discover solutions to make cities more resistant to disaster and violence (De Boer, 2015: 5).

The resilience of cities is a very important feature from which important lessons can be learned. In increasingly unstable and crowded cities; it is not known how it is allocated in informal settlements where $17 \%$ of the world population and $27 \%$ of the city population live (IDMC, 2014). Benefits of increasing disaster resilience come out as; saving life, protecting infrastructure and livelihoods (GFDRR, 2010: 10-11), protecting social systems (IFRC, 2012a: 12), protecting the environment (Standley, 2012), promoting greater resilience in the context of violent conflict or fragility (DFID, 2011: 10).

United Nations Office for Disaster Risk Reduction (UNDRR) launched a campaign in 2010 entitled "Building resilience cities: my city is being prepared". Five metropolitan cities from Turkey such as Istanbul, Kocaeli, Yalova, Antalya and Gaziantep had been included in this campaign. Within the scope of this campaign, a resilient city was explained under nine headings (ISMEP, 2014: 13).

The two most important types of resilience were economic and social resilience. Economic resilience; the ability of an economy to depend on the policy in which it can resist or recover from the effects of external shocks. External shocks here include disasters and natural hazards. The economic impacts of disasters have a direct impact on poverty and human security and may prevent development within a few years (Ranger \& Surminski, 2013: 4).

On the other hand, if resources are limited after an emergency occurs, communities may need to be on their own until assistance arrives. Therefore, it is important to establish social resilience before disasters (RAND, 2011: 1). Adger (2000) defined the first definition of community resilience as a society's ability to cope with external traumas and internal disorders of infrastructure such as political, social and environmental changes (Adger, 2000: 347). In short, the main purpose of community resilience is to increase the capacity and skills of individuals, groups and organizations to cope with discomfort (Obrist et al., 2010: 285). According to the International Federation of Red Cross and Red Crescent Societies (IFRC), a safe and resilience community has six characteristics.

These features are;

a) To be knowledgeable and healthy

b) To be organized

c) To have a wide range of connections and relationships

d) To have strong infrastructure and services

e) To have economic opportunities

f) To manage natural assets (IFRC, 2012b: 7). 


\subsection{Lack of Resilience Indicators}

As a fragility factor, lack of resilience, complementary or reversed treatment of many indicators of human development at all levels, human capital, level of economic redistribution, manageability, financial protection, collective perception, preparedness to face crisis situations, and environmental protection (Table 1). ([Inv]). This set of indicators, themselves and particularly at the local level, can help identify and guide actions that need to be encouraged, strengthened, or prioritized to achieve a higher level of security (Cannon, 2003: 14). Inclusion of risk indicators in the system, effective prevention, mitigation, preparedness and risk taking actions lead to a reduction in risk and on the contrary, effective risk increases occur when these actions do not exist or are insufficient.

Table 1. Lack of Resilience Index Indicators

\begin{tabular}{|c|c|}
\hline Indicator & Description \\
\hline $\begin{array}{l}\text { LR1. Human Development } \\
\text { Index, HDI [Inv] }\end{array}$ & $\begin{array}{l}\text { It represents the level of development of the population, taking into } \\
\text { account life averages, public literacy, schools and incomes of per capita } \\
\text { purchasing power parities. As development increases, so does the capacity } \\
\text { to mitigate risk and face disasters. n }\end{array}$ \\
\hline $\begin{array}{l}\text { LR2. Gender-related } \\
\text { Development Index, GDI [Inv] }\end{array}$ & $\begin{array}{l}\text { It shows the degree of development of the HDI to reflect the inequality of } \\
\text { men and women of the same dimensions. It represents the capacity of } \\
\text { women as human capital. Greater participation and equality means greater } \\
\text { capacity of the population in the face of hardship. }\end{array}$ \\
\hline $\begin{array}{l}\text { LR3. Social expenditures on } \\
\text { pensions, health and education } \\
\text { as a percent of GDP }(\%)[\text { Inv }]\end{array}$ & $\begin{array}{l}\text { It refers to resources aimed at improving the safety of the poorest and } \\
\text { most vulnerable population. Adequate and broad social investment } \\
\text { program coverage reduces the vulnerability of people most affected by } \\
\text { disasters. }\end{array}$ \\
\hline $\begin{array}{l}\text { LR4. Governance Index } \\
\text { (Kaufmann) [Inv] }\end{array}$ & $\begin{array}{l}\text { Public administration represents legitimacy, transparency and } \\
\text { democratization activities. More social management means better } \\
\text { institutionalization, legislation, equity and integration of risk management } \\
\text { into development planning. }\end{array}$ \\
\hline $\begin{array}{l}\text { LR5. Infrastructure and housing } \\
\text { insurance as } \\
\text { a percent of GDP }(\%)[\operatorname{Inv}]\end{array}$ & $\begin{array}{l}\text { Adequate coverage by the insurance industry of possible damages to } \\
\text { residential and public and private products means greater financial } \\
\text { protection of the population against viable threats. }\end{array}$ \\
\hline $\begin{array}{l}\text { LR6. Television sets per } 1000 \\
\text { people [Inv] }\end{array}$ & $\begin{array}{l}\text { Information retrieval through audiovisual technology facilitates efficient, } \\
\text { timely and continuous dissemination of information. Adequate disclosure } \\
\text { and scope improves understanding of risks and disasters and positively } \\
\text { affects better perception and awareness of the population. }\end{array}$ \\
\hline $\begin{array}{l}\text { LR7. Hospital beds per } 1000 \\
\text { people [Inv] }\end{array}$ & $\begin{array}{l}\text { In terms of emergency response, having the sufficient capacity and } \\
\text { infrastructure of the health sector increases the capacity to participate in } \\
\text { the population when disasters and emergencies occur. }\end{array}$ \\
\hline $\begin{array}{l}\text { LR8. Environmental } \\
\text { Sustainability Index, [Inv] }\end{array}$ & $\begin{array}{l}\text { Environmental sustainability means good performance in providing good } \\
\text { environmental conditions for the future. Environmental management has a } \\
\text { positive impact on reducing vulnerability and preventing disasters. }\end{array}$ \\
\hline
\end{tabular}

Reference: Martha Liliana Carreño, Omar Dario Cardona and Alex H. Barbat, "Sistema de indicadores para la evaluación de riesgos",Inter-American Development Bank, 2005, Barcelona, p. 47.

Note: The "Inv" sign in the index factors indicates that the index values are reversed due to the effect direction. In other words, if the index value is calculated as ' $\mathrm{E}$ ', this index value is taken as '1-E'.

Table 1. describes a group of variables defined as general resilience indicators at the national level. These variables, regardless of the nature and severity of these events, captures the capacity to recover or absorb the impact of dangerous events in a macro way (Briguglio, 2003: 5). The lack of solvency is a security vulnerability in dealing with disasters, however it is absolutely necessary to establish this in front of any applicable threat. 


\section{LITERATURE}

When the literature is examined, Inter Development Bank (IDB) has prepared various studies for South American countries.

According to the index study prepared for Argentina; The country's Lack of Resilience Index (LRI) value was found to be 0.50 . Accordingly, while the lower index value of Turkey value (0.50) was observed to be equal to Argentina index (BID, 2010a).

According to the index study prepared for Bahamas, the LRI index value for 2007 is 0.42; this value is seen to be lower than the Turkish index (0.50) (IDB, 2011a).

The index study for Barbados, a Latin American country, shows that the countrywide LRI index value is 0.38 ; this value was quite low than the Turkish index (IDB, 2010a).

According to the index study for Belize in 2011; the country's overall LRI index value was 0.52 ; this value was higher than the Turkish index (0.50) (IDB, 2011b).

According to the index study prepared for Bolivia; the country's LRI index value was 0.56 , and this was higher than that of Turkey (BID, 2010b).

According to the study prepared for Chile the index value in 2015 was 0.35 , and this was lower than that of Turkey (0.50) (BID, 2015a).

According to a study prepared for Costa Rica, the country's LRI index value was 0.51 and this was higher than that of Turkey (BID, 2010c).

According to a study prepared for Ecuador, the country's LRI index value (0.56), was found to be higher than Turkey's index value (0.50) (BID, 2010d).

According to a study conducted for Jamaica in 2004, the LRI index value for the year 2000 was found to be 0.64 . This value was considerably higher than the index value of Turkey (39) (IDB, 2004).

An index study for Colombia was prepared in 2005 by Martha Liliana Carreño, Omar Darío Cardona and Alex H. Barbat. According to the study, LR index value was calculated as 0.43 . This value was a lower value than Turkey (Carreño et al., 2005).

According to the index study prepared for Mexico; LR index value was 0.48 . This value was found to be near to Turkey's value (0.50) (BID, 2015b).

In the index study for Nicaragua in 2015; LRI were 0.63; higher than Turkey (BID, 2015c).

According to Panama index study; LRI value throughout the country was 0.46 , lower than Turkey (0.50) (BID, 2015d).

According to the study conducted in Peru in 2015; the index value of the country for the 1991-2013 period was calculated as 0.51 ; higher than Turkey (BID, 2015e).

In the study prepared for the Dominican Republic in 2010; for the period 1991-2000 the index value was 0.66 , quite high thanTurkey's index value (0.50) (BID, 2010e).

In the index study prepared for the Republic of Suriname, a South American country in 2018; LR country's index was 0.36 , lower than the index of Turkey (IDB, 2018).

According to a study prepared in 2010 for Trinidad and Tobago, a country in the Caribbean; LRI for the 1996-2000 period, the country's index value was 0.65 , it was quite high than Turkey's index value $(0.50)$ (IDB, 2010b).

Table 2. LRI Values of Some Countries

\begin{tabular}{l|c}
\hline \multicolumn{1}{c|}{ Country } & LR Index Value \\
\hline Argentina & 0.50 \\
\hline Barbados & 0.38 \\
\hline Belize & 0.52 \\
\hline Bolivia & 0.56 \\
\hline Dominican Republic & 0.66 \\
\hline Equator & 0.56 \\
\hline El Salvador & 0.61 \\
\hline Guatemala & 0.74 \\
\hline Haiti & 0.68 \\
\hline Honduras & 0.60 \\
\hline Jamaica & 0.65 \\
\hline Colombia & 0.50 \\
\hline Costa Rica & 0.51 \\
\hline Mexican & 0.47 \\
\hline Nicaragua & 0.68 \\
\hline Panama & 0.46 \\
\hline Peru & 0.61 \\
\hline Chile & 0.34 \\
\hline Trinidad and Tobago & 0.65 \\
\hline Turkey & 0.50 \\
\hline Mean & $\mathbf{0 . 5 6}$ \\
\hline
\end{tabular}




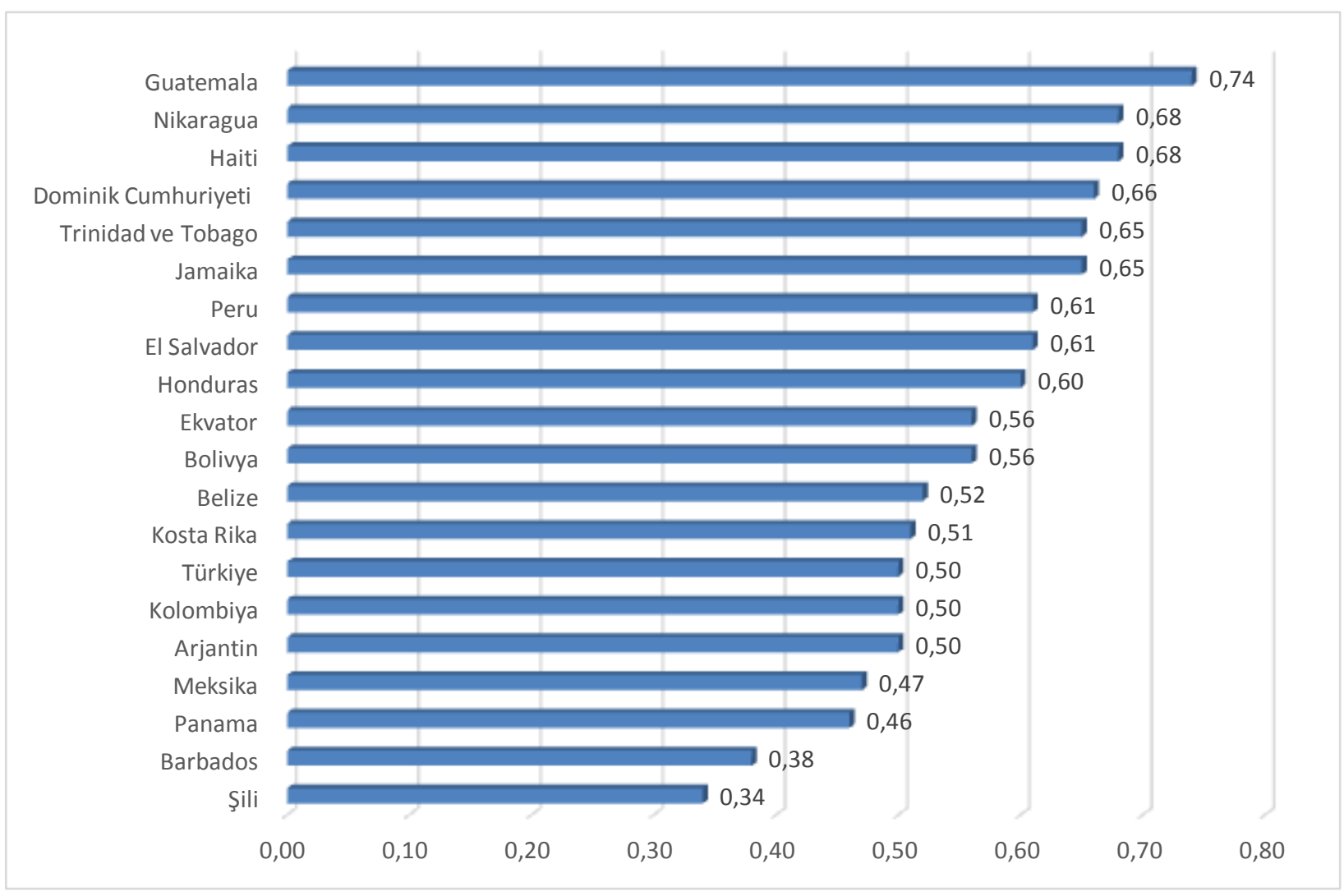

Graphic 1. Ranking of Countries by LRI Values

According to Graph 1. aspect LRI, calculation made out of 20 countries, Turkey was among the lowest 7 countries. Accordingly, the Lack of Resilience Index value of our country was below the average compared to the general average of the other countries. However, our country was in a high category in terms of index values.
However, if the index calculations of more countries can be compared with the developed countries such as European countries, especially with respect to the LR Index, international comparisons and evaluations can be made more accurately.

\section{MATERIALS AND METHODS}

The study is a semi-quantitative study, and the index calculation method is used by weighting from a series of sub-indicators. In other words, the arithmetic averages of the sub-factors that make up the lack of resilience and the other sub-factors that make up these sub-factors are combined with the weighting method.

The aim of the study is to determine the resilience level of the provinces against disasters by using factors affecting human development, economic recovery and reaching a high level of security and guide decision makers at all levels. In addition, the study covers the period between 2015-2017, which includes the most recent data and it was applied to all provinces of Turkey. In addition, the index values of the South American countries that are compared in terms of indexes were obtained from the studies prepared by the Inter Development Bank of America. LRI consists of 8 sub-factors and the index value is between 0 and 1. Classification of index values according to international standards; $0-0.20$ low, 0.20 0.40 medium, $0.40-0.80$ high and $0.80-1.00$ is made in the form of very high.

For Lack of Resilience Index;

1. Human Development Index, HDI [Inv]

2. Gender-related Development Index, GDI [Inv]

3. Social expenditures on pensions, health and education as a percent of GDP (\%) [Inv]

4. Governing Index (Kaufmann) [Inv]

5. Infrastructure and housing insurance as a percent of GDP (\%) [Inv]

6. Television sets per 1000 people [Inv]

7. Hospital beds per 1000 people [Inv]

8. Environmental Sustainability Index, ESI [Inv] sub factors. 
Table 3. Lack of Resilience Index Weights

\begin{tabular}{l|r}
\hline Indicator & Index Weights \\
\hline LR1. Human Development Index, HDI [Inv] & 21.9 \\
\hline LR2. Gender-related Development Index, GDI [Inv] & 10.5 \\
\hline LR3. Social expenditures on pensions, health and education as a percent of GDP (\%) [Inv] & 13.6 \\
\hline LR4. Governing Index (Kaufmann) [Inv] & 15 \\
\hline LR5. Infrastructure and housing insurance as a percent of GDP (\%) [Inv] & 12.9 \\
\hline LR6. Television sets per 1000 people [Inv] & 3.7 \\
\hline LR7. Hospital beds per 1000 people [Inv] & 9.2 \\
\hline LR8. Environmental Sustainability Index, [Inv] & 13.2 \\
\hline
\end{tabular}

RESULTS

The findings of the study are presented in the form of tables, graphs, maps and interpretations.

Table 4. Provinces of 2015-2017 Lack of Resilience Index Indicators

\begin{tabular}{|c|c|c|c|c|c|c|c|c|c|}
\hline Provinces & 2015 & 2016 & 2017 & Mean & Provinces & 2015 & 2016 & 2017 & Mean \\
\hline Adana & 0.51 & 0.51 & 0.51 & 0.51 & Konya & 0.48 & 0.47 & 0.47 & 0.48 \\
\hline Adiyaman & 0.55 & 0.57 & 0.55 & 0.55 & Kütahya & 0.52 & 0.50 & 0.50 & 0.51 \\
\hline Afyon & 0.55 & 0.55 & 0.54 & 0.54 & Malatya & 0.43 & 0.44 & 0.44 & 0.44 \\
\hline Ağn1 & 0.70 & 0.72 & 0.71 & 0.71 & Manisa & 0.54 & 0.54 & 0.54 & 0.54 \\
\hline Amasya & 0.44 & 0.45 & 0.45 & 0.45 & Kahramanmaraş & 0.50 & 0.50 & 0.49 & 0.50 \\
\hline Ankara & 0.33 & 0.32 & 0.32 & 0.32 & Mardin & 0.60 & 0.60 & 0.59 & 0.60 \\
\hline Antalya & 0.46 & 0.47 & 0.47 & 0.47 & Muğla & 0.46 & 0.46 & 0.46 & 0.46 \\
\hline Artvin & 0.43 & 0.43 & 0.43 & 0.43 & Muş & 0.65 & 0.67 & 0.66 & 0.66 \\
\hline Aydin & 0.42 & 0.42 & 0.42 & 0.42 & Nevşehir & 0.51 & 0.52 & 0.51 & 0.51 \\
\hline Balıkesir & 0.53 & 0.53 & 0.53 & 0.53 & Niğde & 0.53 & 0.53 & 0.53 & 0.53 \\
\hline Bilecik & 0.49 & 0.50 & 0.50 & 0.50 & Ordu & 0.44 & 0.44 & 0.44 & 0.44 \\
\hline Bingöl & 0.51 & 0.52 & 0.50 & 0.51 & Rize & 0.41 & 0.41 & 0.40 & 0.41 \\
\hline Bitlis & 0.57 & 0.56 & 0.55 & 0.56 & Sakarya & 0.52 & 0.52 & 0.52 & 0.52 \\
\hline Bolu & 0.37 & 0.39 & 0.38 & 0.38 & Samsun & 0.48 & 0.48 & 0.48 & 0.48 \\
\hline Burdur & 0.44 & 0.43 & 0.43 & 0.43 & Siirt & 0.61 & 0.60 & 0.60 & 0.60 \\
\hline Bursa & 0.43 & 0.43 & 0.43 & 0.43 & Sinop & 0.47 & 0.47 & 0.47 & 0.47 \\
\hline Çanakkale & 0.46 & 0.46 & 0.46 & 0.46 & Sivas & 0.46 & 0.44 & 0.43 & 0.44 \\
\hline Çankırı & 0.50 & 0.51 & 0.51 & 0.50 & Tekirdağ & 0.53 & 0.52 & 0.52 & 0.52 \\
\hline Çorum & 0.41 & 0.42 & 0.42 & 0.42 & Tokat & 0.48 & 0.48 & 0.48 & 0.48 \\
\hline Denizli & 0.45 & 0.44 & 0.43 & 0.44 & Trabzon & 0.38 & 0.39 & 0.38 & 0.38 \\
\hline Diyarbakır & 0.56 & 0.56 & 0.55 & 0.56 & Tunceli & 0.41 & 0.44 & 0.43 & 0.43 \\
\hline Edirne & 0.47 & 0.46 & 0.45 & 0.46 & Şanlıurfa & 0.65 & 0.66 & 0.64 & 0.65 \\
\hline 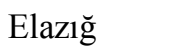 & 0.46 & 0.46 & 0.45 & 0.46 & Uş̧ak & 0.47 & 0.46 & 0.46 & 0.47 \\
\hline Erzincan & 0.45 & 0.47 & 0.46 & 0.46 & Van & 0.61 & 0.61 & 0.59 & 0.60 \\
\hline Erzurum & 0.48 & 0.48 & 0.47 & 0.48 & Yozgat & 0.52 & 0.52 & 0.51 & 0.52 \\
\hline Eskişehir & 0.41 & 0.41 & 0.41 & 0.41 & Zonguldak & 0.49 & 0.49 & 0.49 & 0.49 \\
\hline Gaziantep & 0.59 & 0.58 & 0.58 & 0.58 & Aksaray & 0.54 & 0.54 & 0.54 & 0.54 \\
\hline Giresun & 0.44 & 0.44 & 0.43 & 0.44 & Bayburt & 0.44 & 0.46 & 0.44 & 0.45 \\
\hline Gümüşhane & 0.49 & 0.51 & 0.51 & 0.50 & Karaman & 0.48 & 0.48 & 0.48 & 0.48 \\
\hline Hakkâri & 0.63 & 0.66 & 0.65 & 0.65 & Kırıkkale & 0.44 & 0.44 & 0.43 & 0.44 \\
\hline Hatay & 0.52 & 0.51 & 0.51 & 0.51 & Batman & 0.60 & 0.61 & 0.60 & 0.60 \\
\hline Isparta & 0.38 & 0.39 & 0.37 & 0.38 & Şırnak & 0.65 & 0.67 & 0.66 & 0.66 \\
\hline Mersin & 0.53 & 0.54 & 0.53 & 0.53 & Bartın & 0.49 & 0.50 & 0.49 & 0.49 \\
\hline İstanbul & 0.45 & 0.45 & 0.45 & 0.45 & Ardahan & 0.53 & 0.57 & 0.56 & 0.55 \\
\hline İzmir & 0.36 & 0.36 & 0.36 & 0.36 & Iğdır & 0.57 & 0.59 & 0.58 & 0.58 \\
\hline Kars & 0.55 & 0.56 & 0.55 & 0.55 & Yalova & 0.45 & 0.45 & 0.46 & 0.45 \\
\hline Kastamonu & 0.49 & 0.49 & 0.48 & 0.49 & Karabük & 0.43 & 0.42 & 0.42 & 0.42 \\
\hline Kayseri & 0.51 & 0.51 & 0.51 & 0.51 & Kilis & 0.64 & 0.65 & 0.62 & 0.64 \\
\hline Kirklareli & 0.49 & 0.49 & 0.49 & 0.49 & Osmaniye & 0.52 & 0.52 & 0.52 & 0.52 \\
\hline Kırşehir & 0.47 & 0.48 & 0.47 & 0.47 & Düzce & 0.55 & 0.56 & 0.55 & 0.55 \\
\hline Kocaeli & 0.49 & 0.49 & 0.49 & 0.49 & General Mean & 0.50 & 0.50 & 0.49 & 0.50 \\
\hline
\end{tabular}


Looking at the 2015-2017 period, the provinces with the highest value for 2015 were Ağr1 (0.70), for the year of 2016 were Ağr1 $(0,72)$, for the year of 2017 were Ağrı $(0,71)$ (Table 4).
In addition, according to the results, Ağrı was the province with the highest index value in all three years. On the other hand, Muş and Şırnak provinces were among the provinces with the highest index values in every three years.

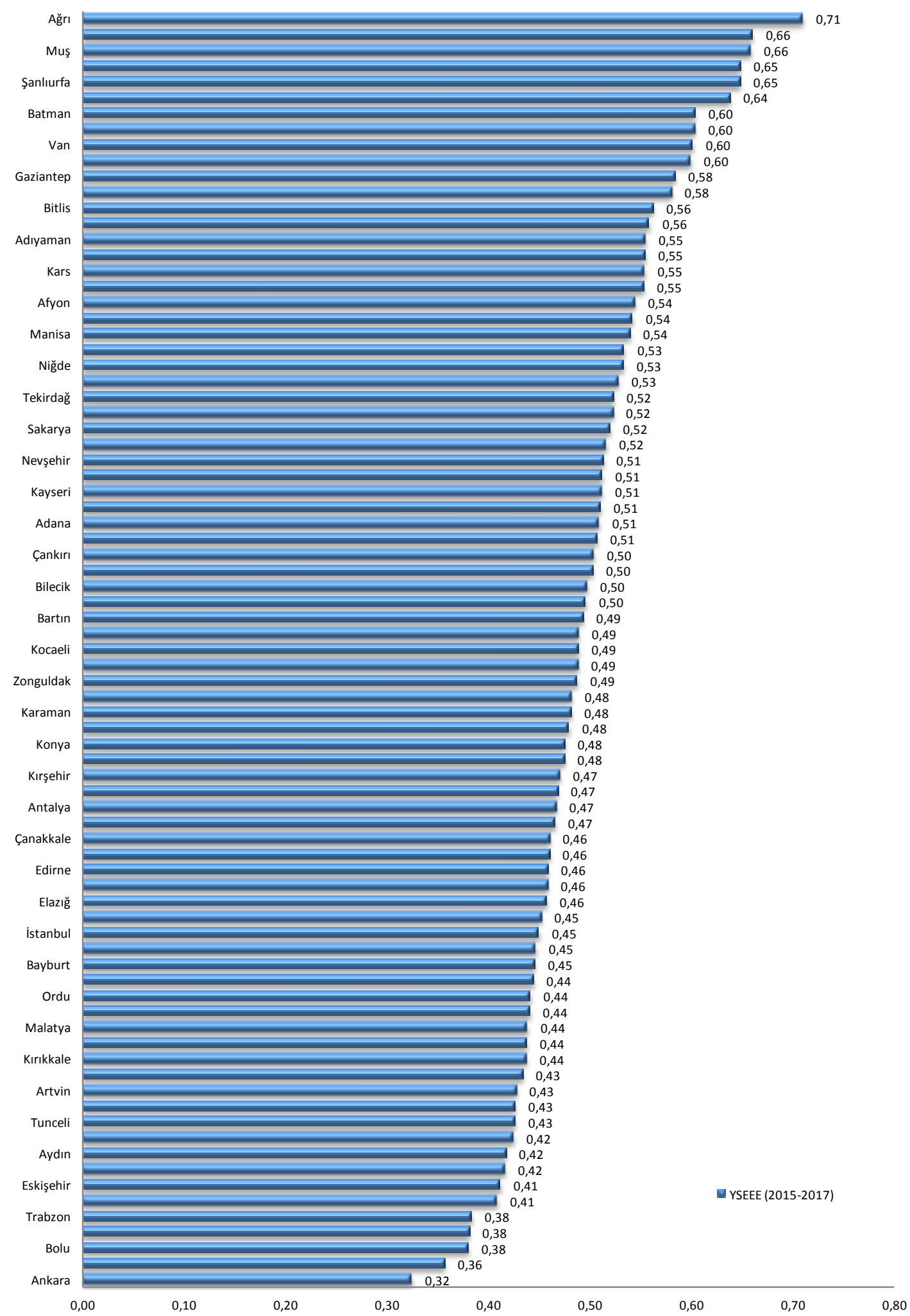

Graphic 2. Provinces of 2015-2017 Lack of Resilience Index Indicators 
According to Graph 2., Ağrı, Şırnak, Muş and Hakkâri were the first four provinces with the highest value. According to the 2015-2017 period averages of Lack of Resilience Index, the last four provinces with the lowest value were Isparta, Bolu, İzmir and Ankara.

In addition, according to the graph, none of the provinces were included in the low index category while only 5 of them were in the middle index category. The remaining 76 provinces were included in the high index category. This shows that $93.83 \%$ of our provinces were in the high category. Furthermore, the percentile has increased compared to the previous period.
Table 5. For the period 2015-2017 Lack of Resilience Classification of Turkish Provinces Averages

\begin{tabular}{|c|c|}
\hline $\begin{array}{l}\text { Lack of } \\
\text { Resilience } \\
\text { Index }\end{array}$ & Provinces \\
\hline$\leq 0.10$ & - \\
\hline $0.11-0.20$ & - \\
\hline $0.21-0.30$ & - \\
\hline $0.31-0.40$ & $\begin{array}{l}\text { Ankara (0.32), İzmir }(0.36), \text { Bolu } \\
(0.38), \text { Isparta }(0.38), \text { Trabzon }(0.38)\end{array}$ \\
\hline $0.41-0.49$ & 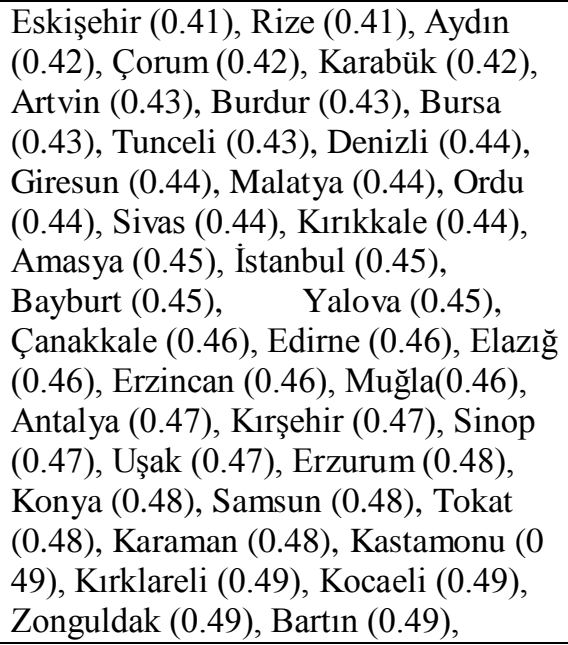 \\
\hline$\geq 0.50$ & 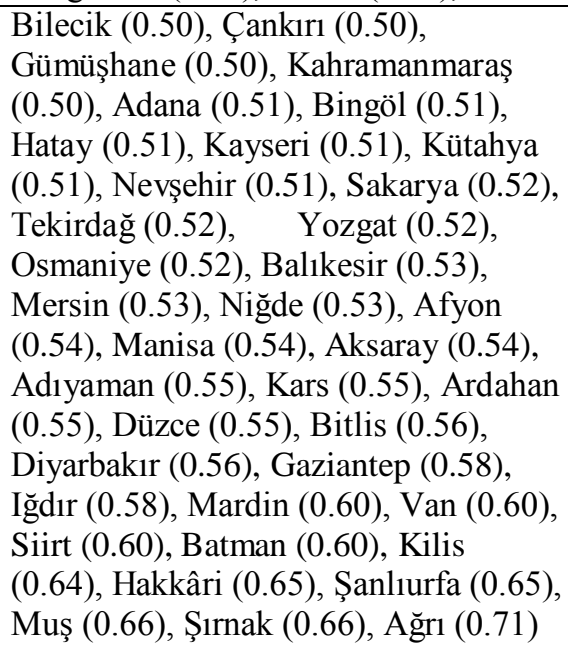 \\
\hline
\end{tabular}

When we look at the 2015-2017 period index classification, we see that the majority of our provinces were concentrated in the value ranges of "0.41-0.49" and " $\geq 0.50$ ". These ranges of values fall into the high category of our index (Table 5). 


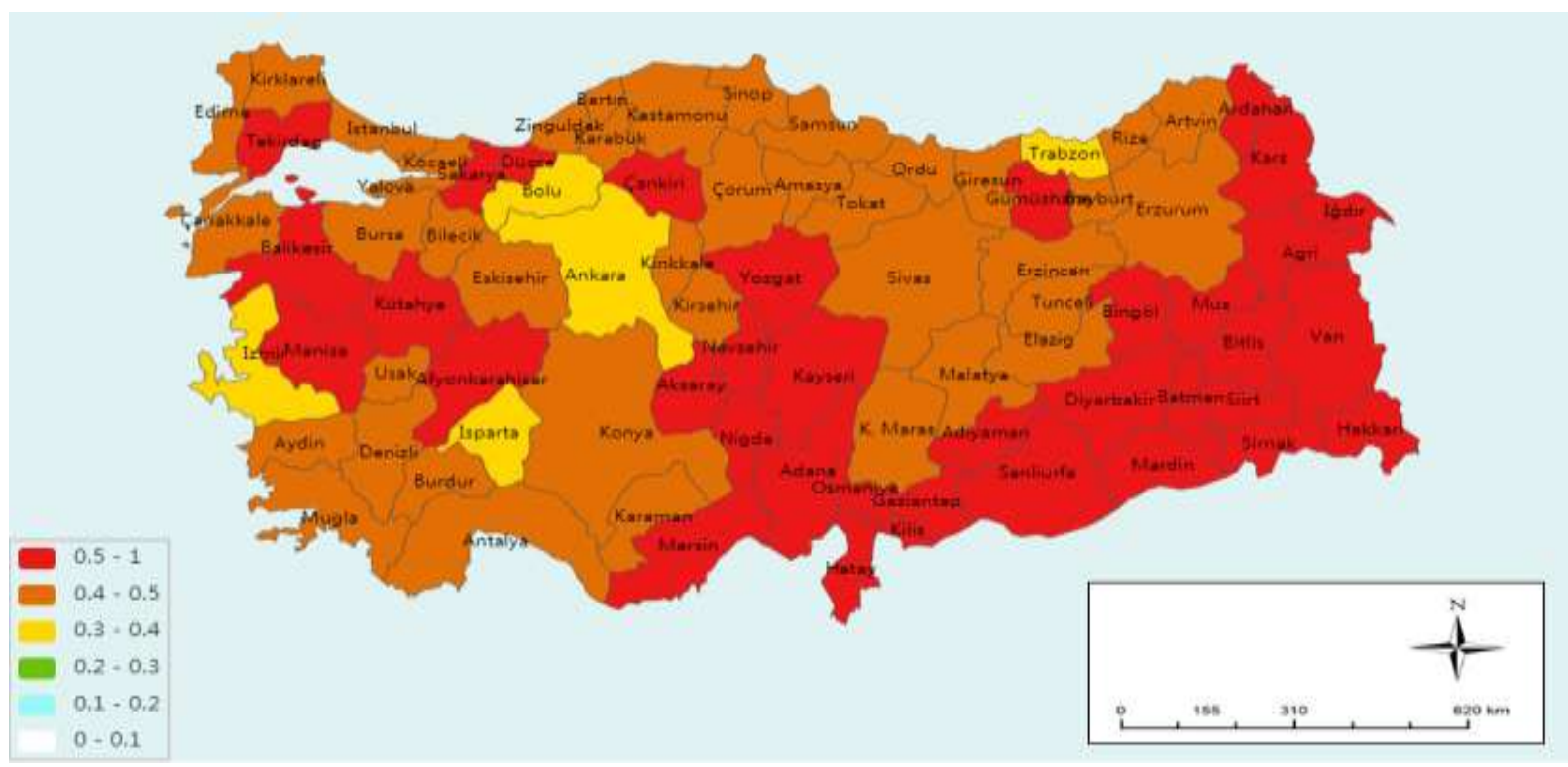

Figure 1. Lack of Resilience Index for 2015-2017 Period

The Lack of Resilience Index is calculated by reversing the index values. Because, the Lack of Resilience Index is composed of indicators such as human development index, gender-based development index, management index, the gross ratio of social expenses related to education, health, accommodation, gross ratio of insurance expenses of buildings and houses and the number of hospital beds per 1000 people. Indicators have a positive effect on vulnerability. For example, the Human Development Index shows the level of development of the population by taking into account the average life expectancy, literacy, purchasing power per capita, and the capacity to cope with disasters increases as the development increases.

In addition, as the social expenditure on education, health and housing increases, the means of increasing the security of the poor and vulnerable population increases; thereby, reducing the vulnerability of the people most affected by disasters. The management index included in this index represents public administration, legitimacy, transparency and democratization activities. A high index means more social management, legislation, equality and integration of risk management into development planning.
In addition, the high insurance costs of buildings and houses mean greater financial protection of the population against threats. The desired number of hospital beds per 1000 people and the number of television per 1000 people, both having sufficient capacity of the health sector in terms of response to emergencies, and facilitating information retrieval, timely and continuous dissemination through visual and audio technology, and a better perception of the population, they have a positive effect on awareness.

According to Figure 1, it is observed that the provinces with high resistance levels are concentrated in the eastern and southeastern regions in the 20152017 period, while the red hue penetrates the inner parts of the Mediterranean coast. In addition, it is remarkable that almost all of our country is in brown and red tones representing the high category. In addition, it is observed that the red color tone includes some education parameters such as east and southeast and social and social elements which are at lower levels in the eastern and southeastern provinces, while it is observed that it is also red in the west such as Manisa, Balıkesir, Kütahya and Düzce. While the color tone of Istanbul province is still brown, the color tone of Izmir province is also yellow.

\section{DISCUSSION}

Many studies have been conducted on the concept of disaster resilience or flexibility, particularly in the international arena.

In this context;

Joseph S. Mayunga (2007), in the draft study report prepared for the summer academy, aimed to develop a conceptual and methodological framework for the analysis, measurement and mapping of the concept of disaster resilience. In this context, while examining the descriptive aspects of the concept of resilience, the frameworks used to measure the flexibility of communities were reviewed and finally, a methodology was proposed by evaluating the index development methods used to measure community resilience against disasters (Mayunga, 2007).

Mac Askill and Guthrie (2014) summarize the problems of the definitions of resilience and emphasize the main issues where there are differences in interpretation. In addition, in the light of these 
differences, a conceptual framework for examining multiple interpretations of resilience in disaster risk management is presented. As a result, the study emphasized that a strict consensus on the definition of resilience is impractical and that adopting it in a number of contexts would be a more accurate approach(Mac Askill and Guthrie, 2014).

In 2016, Benjamin Beccari conducted a comprehensive study on the indicators of disaster risk, vulnerability and compound resilience currently in use. In the study, a comparative analysis of risk, vulnerability and compound resilience indicators related to disasters was performed. Among the new statistical techniques presented here are the CN-TFN index systems, a risk index developed in China, which provides a synthesis of the Regional Disaster Index, the Social Vulnerability Index, the Vulnerability Index for Individuals in Small Households and the Australian Geological Social Vulnerability Index, are broadly compared. As a result, it has been emphasized that there is a significant increase in the number of methodologies applied in recent years and that composite indicators are more usable than the indicators to be used by researchers and policy makers. In addition, the importance of considering the reliability of comparative index systems to allocate resources in order to reduce disaster risk is emphasized in the policies to be implemented ( Beccari, 2016).

The study, prepared by the United Nations University in 2016, presents the findings of a review of 35 frameworks that have become increasingly common to assess fragility, risk and resilience by the international community. This work was prepared to support the development of a conceptual framework to assess the degree of fragility and resilience in cities as part of a wider project initiated by UNU-CPR in 2015. According to the study, frameworks that integrate conceptualization of resilience and fragility are needed to help policy makers to better assess political, economic, social and environmental risks at the city level (UNU-CPR, 2016) .

A report on the Resilience Index was prepared in 2017 by a US-based insurance company specializing in loss prevention services for large companies in the field of high-risk immovable property insurance worldwide. According to the report, three new resilience factors in the index have come to the forefront in recent years. These; urbanization rate, natural cyber risk and supply chain visibility. In the report, 2017 FM Global Resilience Index values were calculated for 130 countries and regions, and comparisons were made with both each other and past values. The rankings were calculated as an equal weighted combination of the 12 core factors that directly and significantly affect the institutional resilience of countries. According to the report, Switzerland ranked first in the 2017 Global Resilience Index. Luxembourg rose from the 8th place in 2013 to the 2nd place in 2017, partly due to a decline in confidence in oil for economic efficiency. In terms of index, Haiti is the lowest country among the poorest countries in the world. In addition, the report includes the rankings of other countries and regions (UNISDR, 2017).

In a project prepared by AFAD (2018), it was aimed to create a new concept of local government that will be implemented both at regional and urban level through specific activities aiming to integrate the concept of 'Resilience' against disasters and climate change into regional development policies. The aim of the project is to encourage municipalities, stakeholders, major groups and communities to implement their local development policies by involving them both in disaster risk mitigation efforts and in increasing the resilience of regions / communities to disasters (AFAD, 2018).

Again in 2018, AFAD organized a workshop titled "The Role of Local Governments in Creating Disaster Resilient Society". According to this workshop, initiated by the UNISDR Resilient Cities Campaign in Turkey, Istanbul, Kocaeli, Yalova, Bursa and Gaziantep, including, five municipalities have been included in the presidency. At the end of the workshop, 100 problem areas were identified through expert opinions and these problems were analyzed in six groups: legislation, institutional administration, cooperation and coordination, capacity, information, training and drill and implementation and supervision.

\section{CONCLUSIONS}

According to the results, it can be seen that among the lowest ten provinces, there were big cities such as Ankara, İzmir, Bolu, Trabzon and Eskişehir.

When sub-indicators were examined for the ten provinces with the lowest index values; The Human Development Index, the Gender-related Development Index 1000 falling number of television per capita, according to Turkey average number of hospital beds per 1,000 people per Environmental Sustainability Index were better than Turkey.
When the provinces with high index values were taken into consideration, it was noteworthy that all of them are the provinces of Eastern and Southeastern Anatolia.

In addition, it is noteworthy that the provinces with high DE index are mostly Eastern and Southeastern provinces. These provinces; The Human Development Index, the Gender-related Development Index, Environmental Sustainability Index, the indicators such as the average number of hospital beds per 1,000 
people under the average of Turkey is seen as inadequate.

Resistance to disasters and hazards means that a region or country will recover quickly, socially, economically, physically, and return to a better state (if possible) after damage and damage occur.

For this reason, for provinces with low DE index; Investment and projects should be prepared and implemented as soon as possible in areas such as average and expected education years, per capita national income, insurance rates of buildings and homes, and the number of hospital beds per person.
In addition, the competent institutions of the countries in the field of disaster management should allocate more budget to the areas that are seen to be inadequate and accelerate the improvements in this field. Thus, the provinces of Turkey and the whole country will be provided with a more durable structure against disasters and environmental hazards (including epidemics and biological threats).

\section{Ethical Approval}

Since there was no issue related to ethical principles in the study, no certificate of ethical compliance was obtained.

\section{REFERENCES}

Adger ,W.N., (2000). Social and ecological resilience: are they related. Progress in Human Geography 24, 3: 347-364.

AFAD (Disaster and Emergency Management), (2018). Afete Dirençli Toplum: Uygulama örnekleri (Disaster Resistant Society: Application examples). Ankara: AFAD Publications.

AFAD (Disaster and Emergency Management), (2018). Disaster Resistant Society: Application examples. Ankara: AFAD Publications.

Beccari, B., (2016). A Comparative Analysis of Disaster Risk, Vulnerability and Resilience Composite Indicators. San Francisco: Public Library of Science (PLOS) Currents Disasters.

BID (Banco Interamericano de Desarrollo), (2010a). Indicadores de Riesgo de Desastre y de Gestión de Riesgos (Argentina). Washington: Banco Interamericano de Desarrollo.

BID (Banco Interamericano de Desarrollo), (2010b). Indicadores de Riesgo de Desastre y de Gestión de Riesgos (Bolivia). Washington: Banco Interamericano de Desarrollo.

BID (Banco Interamericano de Desarrollo), (2010c). Indicadores de Riesgo de Desastre y de Gestión de Riesgos (Costa Rica). Washington: Banco Interamericano de Desarrollo.

BID (Banco Interamericano de Desarrollo), (2010d). Indicadores de Riesgo de Desastre y de Gestión de Riesgos (Ecuador). Washington: Banco Interamericano de Desarrollo.

BID (Banco Interamericano de Desarrollo), (2010e). Indicadores de Riesgo de Desastre y de Gestión de Riesgos (República Domicana). Washington: Banco Interamericano de Desarrollo.

BID (Banco Interamericano de Desarrollo), (2015a). Indicadores de Riesgo de Desastre y de Gestión de Riesgos (Chile). Washington: Banco Interamericano de Desarrollo.

BID (Banco Interamericano de Desarrollo), (2015b). Indicadores de Riesgo de Desastre y de Gestión de Riesgos (México). Washington: Banco Interamericano de Desarrollo.

BID (Banco Interamericano de Desarrollo), (2015c). Indicadores de Riesgo de Desastre y de Gestión de Riesgos (Nicaragua). Washington: Banco Interamericano de Desarrollo.

BID (Banco Interamericano de Desarrollo), (2015d). Indicadores de Riesgo de Desastre y de Gestión de Riesgos (Panamá). Washington: Banco Interamericano de Desarrollo.

BID (Banco Interamericano de Desarrollo), (2015e). Indicadores de Riesgo de Desastre y de Gestión de Riesgos (Perú). Washington: Banco Interamericano de Desarrollo.

Birkmann, J., Cardona, O.D., Carreno, M.L., Barbat, A.H., Pelling, M., Schneiderbauer, S., Kienberger, S., Kelier, M., Alexander, D., Zeil, P. and Welle, T., (2013). Framing vulnerability, risk and societal responses: the MOVE framework. Natural ;Hazards, 67(2): 193-211.
Briguglio, L., (2003). Methodological and practical considerations for constructing socio-economic indicators to evaluate disaster risk. Manizales: Universidad Nacional de Colombia.

Cannon, T., (2003). Vulnerability Analysis, Livelihoods and Disasters Components and variables of vulnerability: modelling and analysis for disaster risk management. Manizales: Universidad Nacional de Colombia.

Cardona, O.D., (2006). A System of Indicators for Disaster Risk Management in the Americas in Measuring Vulnerability to Hazards of Natural Origin: Towards Disaster Resilient Societies. Tokyo: United Nations University Press.

Carreño, M.L., Cardona, O.D. and Barbat, A.H., (2005). Sistema de indicadores para la evaluación de riesgos. Barcelona: Centro Internacional de Métodos Numéricos en Ingenieria.

Carreño, M.L., Cardona, O.D. and Barbat, A.H., (2005). Sistema de indicadores para la evaluación de riesgos. Barcelona: Centro Internacional de Métodos Numéricos en Ingenieria.

Combaz, E., (2014). Disaster Resilience: Topic Guide. Birmingham: GSDRC (Governance and Social Development Resource Centre)

De Boer, J., (2015). Resilience and the Fragile City. International Journal of Security \& Development, 4(1):1-7.

DFID (Department for International Development), (2011). Defining Disaster Resilience: A DFID Approach Paper. London: DFID.

GFDRR (Global Facility for Disaster Reduction and Recovery), (2010). Natural Hazards UnNatural Disaster: The Economics of Effective Prevention. Washington: World Bank.

IDB (Inter American Development Bank), (2004). Information and Indicators Program for Disaster Risk Management-Application of the System of Indicators 1980-2000 (Jamaica). Colombia: InterAmerican Development Bank.

IDB (Inter American Development Bank), (2010a). Indicators for Disaster Risk and Risk Management (Barbados). Colombia: InterAmerican Development Bank.

IDB (Inter American Development Bank), (2010b). Indicators for Disaster Risk and Risk Management (Trinidad and Tobago). Colombia: Inter-American Development Bank.

IDB (Inter American Development Bank), (2011a). Indicators for Disaster Risk and Risk Management (Bahamas). Colombia: InterAmerican Development Bank.

IDB (Inter American Development Bank), (2011b). Indicators for Disaster Risk and Risk Management (Belize). Colombia: InterAmerican Development Bank.

IDB (Inter American Development Bank), (2018). Indicators for Disaster Risk and Risk Management (Suriname). Colombia: InterAmerican Development Bank. 
IDEA (Instituto de Estudios Ambientales), (2005) http://idea.unalmzl.edu.co/ingles/contexto.php (accessed May 30, 2019).

IDMC (International Displacement Monitoring Centre), (2014). Global Estimates 2014: People Displaced by Disaster. Geneva: Imprimerie Harder.

IFRC (International Federation of Red Cross and Red Crescent Societies), (2012a). The long road to resilience: Impact and costbenefit analysis of community-based disaster risk reduction in Bangladesh. Geneva: IFRC.

IFRC (International Federation of Red Cross and Red Crescent Societies), (2012b). Understanding community resilience and program factors that strengthen them. Geneva: IFRC Publising.

Istanbul Seismic Risk Mitigation and Emergency Preparedness Project, (2014). Disaster Resistant City Planning and Construction. İstanbul: İSMEP Publication.

Mac Askill, K. and Guthrie, P., (2014). Multiple interpretations of resilience in disaster risk management. Procedia Economics and Finance, 18: 667-674.

Mac Askill, K., Guthrie, P., (2014). Multiple interpretations of resilience in disaster risk management. Procedia Economics and Finance, 18: 667-74.

Mayunga, J.S., (2007). Understanding and Applying the Concept of Community Disaster Resilience: A capital-based approach, Munich: A draf working paper prepared for the summer Academy for social vulnerability and resilience building, 22-28 July.

Obrist, B., Pfeiffer, C. and Henley, B., (2010). Multi-Layered Social Resilience: A New Approach in Mitigation Research. SAGE
Progress in Development Studies, 10: 283-293. Pelling, M., (2011). Adaptation to Climate Change from Resilience to Transformation. New York: Routledge Taylor \& Francis Group.

RAND (Health Insurance Experiment ), (2011). Building Community Resilience to Disaster. California: RAND Corporation.

Ranger, N. and Surminski, S., (2013). Disaster resilience and post2015 development goals: the options for economics targets and indicators. Leeds: Centre for Climate Change Economics and Policy.

Ranjan, E. S. and AbenaYake, C. C., (2014). A Study on Community's Perception on Disaster Resilience Concept, 4th International Conference on Building Resilience, 8-11 September, United Kingdom.

Standley, S., (2012). Building resilience in a complex environment. Care UK.

UNDRR and WMO, (2012). Disaster Risk and Resilience. Geneva: UNDRR Publishing.

UNDRR, (2009). Terminology on disaster risk reduction (The United Nations Office for Disaster Risk Reduction). http://www.unisdr.org/we/inform/terminology (accessed July, 2019).

UNDRR, (2017). Resilience Index Annual Report. ABD: FM Global.

UNISDR (United Nations Office for Disaster Risk Reduction), (2017). Resilience Index Annual Report. A.B.D: FM Global.

UNU-CPR (United Nations University Centre for Policy Research), (2016). Fragility, Risk, and Resilience: A Review of Existing Frameworks. Tokyo: United Nations University. 